\title{
PARTISIPASI POLITIK MASYARAKAT PADA PEMILIHAN UMUM KEPALA DAERAH DAN WAKIL KEPALA DAERAH DI KABUPATEN KATINGAN
}

\author{
Community Political Participation In Regional Head Election And Regional Head Election \\ In Katingan District
}

\section{Mambang*}

Rudi

Universitas Muhammadiyah Palangkaraya, Palangka Raya, Central Kalimantan, Indonesia

email: mambang@umpalangkaraya.ac..id

\begin{abstract}
Abstrak
Penelitian ini bertujuan untuk mengetahui, mendeskripsikan, dan menganalisis tentang partisipasi politik masyarakat pada Pemilihan Umum Kepala Daerah di Kabupaten Katingan. Metode penelitian yang digunakan adalah deskriptif kualitatif. Peneliti ingin mendeskripsikan tentang bentuk partisipasi politik masyarakat dan pelaksanaan sosialisasi pada pemilihan umum Kepala Daerah dan Wakil Kepala Daerah di Kabupaten Katingan. Sumber data yaitu komisioner KPU Kabupaten Katingan, PKK Katingan Hilir dan Masyarakat yang memiliki hak pilih dalam Pilkada Kabupaten Katingan.

Berdasarkan hasil penelitian dapat disimpulkan bahwa masyarakat sangat antusias mengikuti kampanye, namun kurang antusias dalam memberikan hak suara. Kondisi ini dipengaruhi oleh kondisi sosial ekonomi yang menyebabkan politik transaksional dan masih kurangnya juga kesadaran politik masyarakat. Berdasarkan Hail penelitian ini maka disarankan agar KPU Kabupaten Katingan bersama Pemerintah Daerah Kabupaten Katingan terus melakukan sosialisasi dan pendidikan politik bagi warga masyarakat sehingga pengetahuan, kesadaran politik, dan partisipasi politik di masyarakat lebih meningkat. Selain itu, hendaknya melibatkan tokoh masyarakat dan tokoh agama dalam pelaksanaan sosialisasi dan pendidikan politik sehingga lebih efektif dan efisien, serta diharapkan partisipasi aktif masyarakat untuk berperan aktif dalam pilkada Kabupaten Katingan sebagai bentuk pesta demokrasi lima tahunan.
\end{abstract}

Kata Kunci:

Partisipasi

Politik

Masyarakat

Pemilu

Kepala Daerah

\section{Keywords:}

Participation

Politics

Community

Elections

Regional Head

\begin{abstract}
This study aims to find out, describe, and analyze the community's political participation in the Regional Head General Elections in Katingan Regency. The research method used is qualitative descriptive. The researcher wanted to describe the form of community political participation and the implementation of socialization in the general election of the Regional Head and Deputy Regional Head in Katingan District. Data sources are Katingan Regency KPU commissioner, Katingan Hilir PKK, and Community who have the right to vote in the Katingan Regency Election.

Based on the results of the study it can be concluded that the community was very enthusiastic in participating in the campaign, but was less enthusiastic in giving voting rights. This condition is influenced by socio-economic conditions that cause transactional politics and still lack of public political awareness. Based on the results of this study, it was suggested that the Katingan Regency KPU together with the Katingan District Government continue to carry out socialization and political education for the community so that knowledge, political awareness, and political participation in the community increased. In addition, it should involve community leaders and religious leaders in the implementation of socialization and political education so that it is more effective and efficient, and it is expected that the active participation of the community to play an active role in the Katingan Regency election as a form of the five-year democratic party.
\end{abstract}

\section{Accepted}

Januari 2015

Published

April 2015 mengisi jabatan politik, mulai dari Presiden dan Wakil Presiden, Gubernur dan Wakil Gubernur, Bupati dan Wakil Bupati, Walikota dan Wakil Walikota, Dewan Perwakilan Rakyat (DPR), Dewan Perwakilan Daerah terbentuknya sebuah pemerintahan perwakilan. Pemilu merupakan suatu proses memilih orang-orang untuk 
(DPD), dan Dewan Perwakilan Rakyat Daerah (DPRD) Provinsi dan DPRD Kabupaten/Kota.

Untuk mencapai partisipasi politik masyarakat yang maksimal,maka diperlukan penyebarluasan informasi yang berupa sosialisasi tentang tahapan pelaksanaan pemilu kepada calon pemilih khususnya pemilih pemula. Hal ini disebabkan pemilih pemula baru mengikuti dan melakukan Pemilu untuk pertama kali sehingga berlum mengetahui proses dan prosedur pemilu. Sosialisasi dimaksudkan untuk mengajak warga masyarakat yang memiliki hak pilih untuk menggunakan hak pilihnya dalam pemilu.

Salah satu Kabupaten di Provinsi Kalimantan Tengah yang telah melakukan Pemilihan Umum Kepala Daerah dan Wakil Kepala Daerah (Pilkada) adalah kabupaten Katingan pada tanggal 4 April 2013 yang lalu.

Kabupaten Katingan teridiri dari 13 kecamatan, 161 kelurahan/desa, dengan jumlah penduduk. 170.295 orang. Berdasarkan keputusan Komisi Pemilihan Umum Kabupaten Katingan Nomor: I3/KPTS/KPUKab/020.43582I/II/2013 tendang Penetapan Jumlah Pemilih Terdaftar dan Jumlah Tempat Pemungutan Suara (TPS) dalam Pemilihan Umum Bupati dan Wakil Bupati katingan tahun 2013, jumlah pemilih tetap yaitu sebanyak 55.578 orang.

Dalam pelaksanaan Pilkada di Kabupaten Katingan sebagai penyelanggara Pilkada yaitu Komisi Pemilihan Umum (KPU) Kabupaten Katingan untuk kabupaten, 13 panitia pemilihan Kecamatan (PPK) untuk penyelenggaraan di tingkat kecamatan, $16 \mid$ Panitia Pemungutan Suara (PPS) untuk penyelenggara di tingkat kelurahan/desa dan 340 Kelompok Panitia Pemungutan Suara (KPPS) untuk penyelenggara di TPS. Untuk itu diharapkan bagi masyarakat yang sudah terdaftar sebagai pemilih tetap dapat berpartisipasi dalam memberikan hak pilihnya pada Pilkada Kabupaten Katingan.
Pentingnya pemilu belum seutuhnya disadari oleh seluruh masyarakat Kabupaten Katingan. Hal ini terlihat dari indikasi: (I)Warga/ masyarakat terlihat masa bodoh dan tidak peduli terhadap penyelenggaraan Pemilu; (2) Masyarakat cenderung lebih memeilih bekerja untuk menafkahi keluarha daripada memberikan hak suara; (3) Warga/masyarakat yang memiliki hak suara tidak hadir ke Tempat Pemungutan Suara (TPS) pada hari pemungutan suara, dimana darihasil rekapitulasi KPU Katingan jumlah masyarakat yang tidak menggunakan hak suaranya sebesar $34,21 \%$ (39.820 orang).

\section{Partisipasi}

Menurut Scumpeter (Damsar, 2010:24) bahwa: "Partisipasi politik masyarakat berkaitan erat dengan demokrasi suatu negara. Dalam negara demokratis, kedaulatan tinggi berada di tangan rakyat, yang melaksanakan melalui kegiatan bersama untuk menetapkan tujuan-tujuan, serta masa depan dan untuk menentukan orang-orang yang akan memegang tampuk pimpinan". Dengan kata lain, partisipasi langsung dari masyarakat yang seperti ini merupakan pengejawantahan dan penyelanggaraan kekuasaan politik yang absah dan oleh rakyat. Keikutsertaan masyarakat dalamberpartisipasi sangatlah penting karena teori demokrasi menyebutkan bahwa masyarakat tersebut sangatlah mengetahui apa yang mereka kehendaki. Hak-hak sipil dan kebebasan dihormati serta dijunjung tinggi. Tiada demokrasi tanpa partisipasi politik warga, sebab partisipasi merupakan esensi dari demokrasi. Partisipasi atau keterlibatan masyarakat dalam berpolitik merupakan ukuran demokrasi suatu negara.

Sebagai proses dari transformasi politik, masyarakat mengharapkan agar Pilkada dapat menghasilkan Kepala daerah yang akuntabel, berkualitas, Legitimate, dan peka terhadap kepentingan masyarakat, bukan Kepala Daerah yang hanya mementingkan kepentingan pribadi atau golongannya saja. Bentuk partisipasi politik seseorang dapat dilihat dengan jelas melalui aktivitas- 
aktivitas politiknya. Begitu juga dalam masyarakat dapat dilihat dari aktivitas-aktivitas yang dilakukan bersama oleh masyarakat.

Berdasarkan pendapat Mas'oed dan McAndrews (2001:47) "Kegiatan politik konvensional adalah bentuk partisipasi politik yang normal dalam demokrasi modern sedangkan bentuk non konvensional termasuk beberpaa yang mungkin legal maupun yang illegal, penuh kekerasan, dan revolusioner.

Partisipasi politik menurut McClosky (Damsar, 2010:108) dapat diartikan sebagai "kegiatankegiatan sukarela dari warga masyarakat melalui mana mereka mengambil bagian dalam proses pemilihan [enguasa dan secara langsung atau tidak langsung dalam proses pembentukan kebijakan umum". Pendapat McClosky menekankan partisipasi politik masyarakat berupa kegiatan-kegiatan sukarela yang dilakukan oleh warga Negara serta warga negara terlibat dalam proses-proses politik.

Beberapa kriteria dari pengertian partisipasi politik menurut Ambardi (2009:288-290) adalah:

I. Menyangkut kegiatan-kegiatan yang dapat diamati dan bukan sikap atau orientasi. Jadi, partisipasi politik hanya berhubungan dengan ha; yang bersifat objektif dan bukan subjektif

2. Kegiatan politik warga negara biasa atau perorangan sebagai warga negara biasa yang dilaksakan secara langsung (perantara)

3. Kegiatan tersebut bertujuan untuk mempengaruhi pengambilan keputusan pemerintah, baik berupa bujukan atau dalam bentuk tekanan bahkan penolakan juga terhadap keberadaan figur para pelaku politik dan pemerintah.

4. Kegiatan tersebut diarahkan kepada upaya mempengaruhi pemerintah tanpa perduli efek yang akan timbul gagal atau berhasil.

5. Kegiatan yang dilakukan dapat melalui prosedur yang wajar dan tanpa kekerasan (konvensional) maupun dengan cara yang diluar prosedur yang wajar (tak konvensional) dan berupa kekerasan.

6. Partisipasi politik adalah kegiatan seseorang atau sekelompok orang untuk ikut serta secara aktif dalam kehidupan politik seperti memilih pimpinan negara atau upaya-upaya mempengaruhi kebijakan pemerintah.

\section{Bentuk Partisipasi Politik Masyarakat}

Adanya kebebasan rakyat dalam menjalankan partisipasi politik menjadi ukuran untuk melihat eksistensi demokrasi dalam suatu negara. Ada banyak bentuk partisipasi politik itu sendiri, diataranya melalui pemberian suara (voting behavior), diskusi politik, kegiatan kampanye, ikut dalam partai politik, dan lain sebagainya.

Michael Rush dan Philip Althoff (Damsar, 2010:185) mengidentifikasi bentuk-bentuk partisipasi pollitik sebagai suatu tipologi politik. "Hirarki tertinggi dari partisipasi politik adalah menduduki jabatan politik atau administratif. Sedangkan hirarki yang terendah dari suatu partisipasi politik adalah orang yang apati secara total, yaitu orang yang tidak melakukan aktivitas politik apapun secara total. Semakintinggi hirarki partisipasi politik maka semakin kecil kuantitas dari keterlibatan orang-orang".

Menurut Surbakti (2003:74), bentuk partisipasi diberdakan menjadi partisipasi aktif dan partisipasi pasif:

I. Partisipasi aktif mencakup kegiatan warga negara mengajukan usul mengenai suatu kebijakan umum, mengajukan alternatif kebijakan umum yang berbeda kepada pemerintah, mengajukan kritik dan saran perbaikan untuk meluruskan kebijaksanaan, membayar pajak dan ikut dalam kegiatan pemiliha pimpinan pemerintahan.

2. Partisipasi pasif berupa kegiatan mentaati peraturan pemerintah, menerima, dan melaksanakan begitu saja setiap keputusan pemerintah. 


\section{Faktor yang Mempengaruhi Partisipasi Politik Masyarakat}

Slamet (Mardikanto dan Soebito, 2015:91) menyatakan bahwa tumbuh dan berkembangnya partisipasi masyarakat dalam pembangunan sangat ditentukan oleh tiga unsur pokok, yaitu :

I. Adanya kesempatan masyarakat untuk berpartisipasi

2. Adanya kemauan yang diberikan kepada masyarakat

3. Adanya kemampuan masyarakat untuk berpartisipasi

Menurut Easton (Sastroatmojo, 2005:92-94) bahwa faktor-faktor yang mempengaruhi partisipasi politik masyarakat, yaitu:

I. Faktor Sosial Ekonomi

2. Faktor Politik, meliputi:

a. Komunikasi Politik

b. Kesadaran Politik

c. Pengetahuan Masyarakat Terhadap Proses Pengambilan Keputusan

d. Kontrol Masyarakat Terhadap Kebijakan Publik

3. Faktor Nilai Budaya

\section{METODOLOGI}

Metode penelitian yang digunakan adalah deskriptif kualitatif. Peneliti ingin mendeskripsikan tentang bentuk partisipasi politik masyarakat dan pelaksanaan sosialisasi pada pemilihan umum Kepala Daerah dan Wakil Kepala Daerah di Kabupaten Katingan. Sumber data yaitu komisioner KPU Kabupaten Katingan, PKK Katingan Hilir dan Masyarakat yang memiliki hak pilih dalam Pilkada Kabupaten Katingan. Dalam pengumpulan datanya, peneliti menggunakan observasi langsung, wawancara mendalam, FGD dan dokumentasi.

\section{HASIL DAN PEMBAHASAN}

\section{Partisipasi Politik Masyarakat}

I. Partisipasi Politik Masyarakat Dalam Kampanye Menurut ketua KPU Kabupaten Katingan (Sapta Tjita, S.Sos, 13 Mei 2015) bahwa kampanye merupakan salah satu tahapan dalam Pemilihan Kepala Daerah dan Wakil Kepala Daerah Kabupaten Katingan. Untuk itu diharapkan setiap pasangan calon (paslon) untuk memberikan visi dan misinya kepada masyarakat dengan tetap menjaga keamanan dan ketertiban. Selain itu, diharapkan masyarakat yang mengikuti kampanye juga harus menjaga ketertiban dan keamanan serta tidak membawa anak-anak dalam kampanye. Hasil wawancara dengan masyarakat (Yuliandhi,20I5) menjelaskan bahwa partisipasi politik yang mereka lakukan untuk ikut kampanye karena mereka suka terhadap figur yang diusungnya sehingga mereka menghadiri kampanye untuk mendengarkan visi dan misi pasangan calon Bupati dan Wakil Bupati Kabupaten Katingan. Selain itu masyarakat menghendaki agar apa yang sekarang dikampanyekan kelak dapat direalisasikan bilamana mereka terpilih.

Masyarakat sangat antusias untuk mengikuti kampanye terbuka terutama yang berusia muda. Apalagi dalam kampanye ini juga dihadirkan hiburan musik, sehingga kampanye semakin menarik dan semarak.

2. Partisipasi Politik Masyarakat Dalam Pemungutan Suara

Bahwa mereka yang menggunakan hak pilihnya dengan tujuan untuk memenangkan pasangan calon yang dijagokan agar melakukan perubahan ke arah yang lebih baik sehingga masyarakat lebih sejahtera. Selain itu, memberikan suara merupakan bentuk kesadaran sebagai warga negara yang harus ikut mensukseskan kegiatan pemerintah. 


\begin{abstract}
Pemilihan Kepala Daerah dan Wakil Kepala Daerah Kabupaten Katingan tahun memberikan gambaran yang nyata tentang bentuk partisipasi politik masyarakat Kabupaten Katingan yaitu:
\end{abstract}

I. Keikutsertaan beberapa warga sebagai Kelompok Panitia Pemungutan Suara (KPPS) yang masing-masing Tempat Pemungutan Suara (TPS) 8 orang menjadi anggota KPPS dan 2 orang menjadi hansip sebagai keamanan.

2. Keikutsertaan beberpaa warga masyarakat sebagai anggota Panitia Pemungutan Suara (PPS) dan Panitia Pemilihan Kecamatan (PPK)

3. Beberapa warga yang menjadi saksi pada pemungutan suara

4. Beberapa warga masyarakat yang menjadi tim sukses dari masing-masing pasangan calon Bupati dan Wakil Bupati Kabupaten Katingan

5. Dalam pelaksanaan pemungutan suara partisipasi politik masyarakat sebesar $60,46 \%$ yang tersebar di berbagai pasangan calon Bupati dan Wakil Bupati Kabupaten Katingan

Menurut ketua KPU Kabupaten Katingan Sapta Tjita,S.Sos bahwa tingkat partisipasi masyarakat dalam memilih yaitu mencapai $60,46 \%$ dari Daftar Pemilih Tetap (DPT), ini mencerminkan bahwa masyarakat sudah mulai sadar akan arti penting ikut dalam pemilu.

Dengan tingkat partisipasi yang mencapai 60,46\% dalam putaran pertama Pilkada Bupati dan Wakil Bupati Kabupaten Katingan menunjukan bahwa masyarakat telah memberikan partisipasi aktif dalam bentuk Partisipasi Konvensional yaitu dengan memberikan hak suara dalam Pilkada. Untuk itu diharapkan KPU Kabupaten Katingan terus melakukan sosialisasi guna meningkatkan partisipasi politik masyarakat dalam putaran kedua Pilkada Kabupaten Katingan.

\section{Faktor-faktor Yang Mempengaruhi Partisipasi} Politik Masyarakat

I. Faktor Sosial Ekonomi

Faktor sosial-ekonomi turut mempengaruhi tingkat partisipasi politik masyarakat. Umumnya, orang yang sejahtera dan makmur hidupnya akan lebih aktif daripada orang yang kurang makmur, laki-laki akan lebih aktif daripada perempuan. Tetapi perubahan yang terjadi saat ini adalah kelompok etnis yang dominan akan lebih aktif daripada minoritas, dan orang tua (kecuali yang sangat tua) akan lebih aktif daripada anak-anak muda.

Bahwa memilih pasangan calon yang satu dan yang lainnya adalah sama saja tergantung siapa sekarang yang mau memberi uang atau barang, bukan hanya janji-janji saja. Mereka juga beranggapan lebih baik ke hutan mencari rotan daripada ikut pilkada tapi tidak dapat uang. Kecuali ada pasangan calon yang mau mengganti satu hari jam kerjanya dengan uang.

Tingkat sosial ekonomi masyarakat juga berakibat pada mudahnya terjadi money politics dalam pilkada Kabupaten Katingan. Tidak jarang tim sukses akan membagi-bagiikan uang atau barang untuk mengganti suara mereka dalam pilkada. Kondisi ini terjadi karena masyarakat berpikir praktis bahwa memilih siapaun sama saja, yang penting mendapat uang atau barang yang bisa dimanfaatkan untuk mencukupi kebutuhan seharihari.

2. Faktor Politik

Setiap aktivitas partisipasi politik masyarakat cenderung menggunakan prinsip siapa melakukan apa, dengan apa, dan mendapat apa. Setiap aktivitas tim sukses pasangan calon selalu berorientasi menarik dukungan sebanyakbanyaknya dari masyarakat. Sedangkan masyarakat berpandangan bahwa setiap dukungan yang diberikan harus ada imbalannya, baik berupa barang 
maupun uang, seehingga muncullah Politik transaksional. Dalam faktor politik sangat dipengaruhi oleh beberapa hal yaitu:

a. Komunikasi Politik

Merupakan komunikasi persuasi yang selalu dilakukan oleh pasangan calon Kepala Daerah dan Wakil Kepala Daerah Kabupaten Katingan, partai politik dan tim sukses untuk mencapai tujuan politiknya.

Komunikasi politik yang dilakukan antara pasangan calon Bupati dan Wakil Bupati Kabupaten Katingan dapat berupa:

I. Propoganda Politik

2. Public Relationship

3. Lobby Politik

4. Periklanan Politik

b. Kesadaran Politik

Adalah kesadaran masyarakat akan haknya untuk menggunakan suaranya dalam Pilkada. Kesadaran yang berorientasi pada makna perubahan dan perbaikan dibanding hanya untuk mendapatkan sekarung beras atau beberapa lembar uang ratusan ribu dalam Pemilihan Kepala Daerah dan Wakil Kepala Daerah.

Tak dapat dipungkiri bahwa hampir mayoritas pemilih di Kabupaten Katingan masih memilih pasangan calon Bupati dan Wakil Bupati berdasarkan orang yang sering memberi bantuan , baik uang maupun bahan pangan kepada mereka. Ini berarti bahwa partisipasi politik masyarakat telah menggunakan partisipasi praktis dan partisipasi transaksional. Nilai kesadaran politik masyarakat masih harus terus ditingkatkan dan harus diberikan pendidikan politik sehingga tidak berorientasi pada kepentingan sesaat dan bersifat transaksional.

Kesadaran politik masyarakat dapat dibangun melalui pendidikan politik. Melalui pendidikan politik diharapkan kader-kader anggota partai politik tersebut akan memperoleh manfaat atau kegunaan, diantaranya:
I. Dapat memperluas pemahaman, penghayatan, dan wawasan terhadap masalah-masalah atau isu-isu yang bersifat politis.

2. Mampu meningkatkan kualitas diri dalam berpolitik dan berbudaya politik sesuai dengan peraturan perundang-undangan yang berlaku.

3. lebih meningkat kualitas kesadaran politik rakyat menuju peran aktif dan partisipasinya terhadap pembangunan politik bangsa secara keseluruhan.

c. Pengetahuan Masyarakat

Partisipasi politik masyarakat sangat dipengaruhi oleh tingkat pengetahuan masyarakat. Bahwa mereka mengetahui pasangan calon Bupati dan Wakil Bupati Katingan dari pamflet atau brosur yang dibagibagikan oleh tim sukses. Selain itu, mereka juga mengetahui pasangan calon dari acara TVRI Kalimantan Tengah dan juga dari media massa seperti Kalteng Pos dan Tabengan. Dengan mengetahui profil masing-masing pasangan calon, masyarakat dapat mengetahui latar belakang pasangan calon dan visi misi pasangan calon sehingga dapat menambah keyakinan untuk memilih atau tidak memilihnya.

Pengetahuan masyarakat tidak lepas dari tingkat dan jenjang pendidikan yang dienyam oleh masyarakat. Semakin tinggi tingkat pendidikan maka tingkat pengetahuannya pun semakin tinggi. Pengetahuan masyarakat sangat dipengaruhi oleh tingkat pendidikan masyarakat dan akses informasi yang diterima masyarakat. Semakin masuk ke pedalaman Kabupaten Katingan maka akses informasi semakin kecil karena hanya mengandalkan informasi dari media elektronik yaitu TV dan radio.

Perlu adanya pengetahuan masyarakat terhadap pemahaman dan pendidikan politik sejak dini. Adapun upaya yang bisa dilakukan 
untuk meningkatkan pengetahuan masyarakat adalah sebagai berikut:

I. Peningkatan tingkat pendidikan masyarakat dengan cara melanjutkan ke pendidikan formal di sekolah mulai jenjang sekolah dasar sampai perguruan tinggi

2. Mengikut pendidikan informal melalui pelatihan-pelatihan dan kelompok belajar (kerja)

3. Peningkatan aksesibilitas informasi melalui penyediaan layanan informasi masyarakat di tiap-tiap wilayah pedesaan maupun perkampungan

4. Penambahan sarana pendidikan baik gedung sekolah, buku bacaan, dan sarana pembelajaran.

5. Penambahan tenaga pendidik di pedalaman

6. Peningkatan kesejahteraan guru di pedalaman

\section{d. Kontrol Masyarakat}

Hasil wawancara dengan masyarakat, Yuliandhi menjelaskan bahwa untuk memilih pasangan Calon Kepala Daerah dan Wakil Kepala Daerah adalah dengan cara menilai perilaku dan prestasi pasangan calon. Salah satu penyebab munculnya golongan putih (Golput) dalam Pilkada Kabupaten Katingan adalah akibat dari kontrol masyarakat (persepsi masyarakat), karena masyarakat menilai selama ini antara memilih dan tidak memilih sama saja, tidak ada pengaruh terhadap kehidupan sosial ekonomi mereka. Mereka menganggap memilih tidak penting, ikut Pilkada tidak penting, ikut kampanye tidak penting karena tidak bisa langsung mengubah nasib mereka.

\section{Faktor Nilai Budaya}

Budaya politik adalah aspek politik dari nilai-nilai yang terdiri atas pengetahuan,adat istiadat, takhayul, dan mitos. Semuanya dikenal dan diakui oleh sebagian besar masyarakat. Budaya politik tersebut memberikan alasan rasional untuk menolak atau menerima nilai-nilai dan norma lain, termasuk untuk berpartisipasi dalam Pilkada.

Ada tiga hal yang terkait dengan nilai budaya, yaitu:

I. Simbol-simbol, slogan atau yang lainnya yang kelihatan kasat mata

2. Sikap, tingkah laku, gerak-gerik yang muncul akibat slogan/moto terebut

3. Kepercayaan yang tertana, (believe system) yang mengakar dan menjadi kerangka acuan dalam bertindak dan berperilaku (tidak terlihat)

\section{KESIMPULAN}

I. Partisipasi politik masyarakat dalam Pilkada Kabupaten Katingan dapat dilihat dari dua bentuk partisipasi, yaitu partisipasi dalam mengikuyi kampanye dan partisipasi dalam pemungutan suara. Pada partisipasi dalam kampanye masyarakat sangat antusias mengikuti kampanye masing-masing pasangan calon Kepala Daerah dan Wakil Kepala Daerah. Sedangkan partisipasi dalam pemungutan suara, masyarakat ikut berpartisipasi menjadi anggota KPPS, PPS, dan PPk serta memberikan hak suara dalam Pilkada Kabupaten Katingan dengan tingkat partisipasi sebesar $60,46 \%$.

2. Partisipasi politik masyarakat dipengaruhi oleh faktor sosial ekonomi yaitu mendorong munculnya politik transaksional. Kemudian faktor politik yang berkaitan dengan komunikasi politik, kesadaran politik, pengetahuan masyarakat, dan kontrol masyarakat menjadi faktor pendorong bagi masyarakat untuk antusias memberikan hak suaranya. Sedangkan faktor nilai budaya dengan tipe budaya politik tradisional menjadi pegangan masyarakat dalam menentukan pasangan calon yang dipilih dalam Pemilihan Umum Kepala Daerah dan Wakil Kepala Daerah di Kabupaten Katingan 


\section{REFERENSI}

Anggara, Sahaya. 20I4. Kebijakan Publik. Bandung : CV Pustaka Setia.

Ambardi, Kuskridho. 2009. Mengungkap Politik Kartel. Jakarta: Kepustakaan Populer Gramedia

Damsar. 2010. Pengantar Sosiologi Politik. Jakarta: Kencana Prenada Media Group.

Hamdi, Muchlis. 20I4. Kebijakan Public Proses, Analisis, dan Partisipasi. Bogor : Ghalia Indoneisa

Mardikanto, Totok dan Poerwoko Soebito. 20I4.Pemberdayaan Masyarakat Dalam Perspektif Kebijakan Publik. Bandung: Alfabeta.

Mas'oed, Mohtar dan MacAndrews. 200I. Perbandingan Sistem Politik. Yogyakarta: Gadjah Mada University Press.

Mulyadi, Deddy. 2014. Studi Kebijakan Publik dan Pelayanan Publik. Bandung : Alfabeta.

Winarno, Budi. 20I4. Kebijakan Publik (Teori, Proses dan Studi Kasus). Caps. Yogyakarta.

Widodo, Joko. 2012. Analisis Kebijakan Publik. Malang : Media Nusa Creative 